Pesq. Vet. Bras. 37(5):447-452, maio 2017 DOI: $10.1590 /$ S0100-736X2017000500004

\title{
Species identification and antimicrobial susceptibility profile of bacteria causing subclinical mastitis in buffalo ${ }^{1}$
}

\author{
Andrea Vásquez-García², Thaysa dos Santos Silva ${ }^{3}$, Sabrina R. de Almeida- \\ Queiroz $^{4}$, Silvia H.S. Godoy ${ }^{4}$, Andrezza M. Fernandes ${ }^{4}$, Ricardo L.M. Sousa ${ }^{4}$ \\ and Raul Franzolin ${ }^{5 *}$
}

\begin{abstract}
Vásquez-García A., Silva T.S., Almeida-Queiroz S.R., Godoy S.H.S., Fernandes A.M., Sousa R.L.M. \& Franzolin R. 2017. Species identification and antimicrobial profile of bacteria causing subclinical mastitis in buffalo. Pesquisa Veterinária Brasileira 37(5):447-452. Departamento de Zootecnia, Faculdade de Zootecnia e Engenharia de Alimentos, Universidade de São Paulo, Av. Duque de Caxias Norte 225, Pirassununga, SP 13635-900, Brazil. E-mail: rfranzol@usp.br

Microorganisms causing subclinical mastitis in water buffalo were isolated from 20 buffalo milk samples at four dairy farms located in central region of São Paulo State, Brazil, through testing of somatic cell count (SCC), standard plate count (SPC), biochemical, PCR assays and antimicrobial profile. The SCC showed average of 721,000 cells $/ \mathrm{mL}$ in the milk, indicating the presence of subclinical mastitis. The overall average for SPC was 1.8 x $10^{4} \mathrm{CFU} / \mathrm{mL}$. The microorganism most frequently isolation according to biochemical tests were: Staphylococcus epidermidis (17\%), Staphylococcus aureus (15\%), Bacillus spp. (14\%), Acinetobacter spp. (12.5\%); with intermediate frequency: Pseudomonas aeruginosa (9.5\%); Shigella flexneri (7.0\%), Streptococcus spp. (5.5\%), Corynebacterium spp. (5.0\%), Escherichia coli (4.5\%), Serratia marcescens (4.0\%), Stenotrophomonas maltophilia (4.0\%), and low incidence: Klebsiella rhinoscleromatis (0.5\%), Klebsiella ozaenae $(0.5 \%)$, Tatumella ptyseos $(0.5 \%)$, Enterobacter cloacae $(0.5 \%)$. The molecular analysis indicated that samples positive by culture method of the genera Staphylococcus, Streptococcus and E. coli were positive by PCR. Para S. aureus and S. epidermidis the highest percentages of observed sensitivity were gentamicin (100\%) and vancomycin (100\%); for the genus Streptococcus to gentamicin and oxacillin and E. coli to Ampicilin. These findings may help in the control and treatment of subclinical mastitis in buffaloes and contribute to improving the efficiency and quality of the milk produced.
\end{abstract}

INDEX TERMS: Antimicrobial profile, mastitis, buffalo, antibiotics, bacteria, somatic cell count, milk.

RESUMO.- [Identificação de espécies e perfil de susceptibilidade antimicrobiano de bactérias causadoras de mastite subclínica em búfalos.] Microrganismos causa-

\footnotetext{
${ }^{1}$ Received on December 11, 2015

Accepted for publication on September 1, 2016.

${ }^{2}$ Programa de Pós-Graduação em Ciências, Departamento de Engenharia de Alimentos, Faculdade de Zootecnia e Engenharia de Alimentos (FZEA), Universidade de São Paulo (USP), Av. Duque de Caxias Norte 225, Pirassununga, SP 13635-900, Brazil.

${ }^{3}$ Programa de Pós-Graduação em Zootecnia, Departamento de Zootecnia, FZEA-USP, Av. Duque de Caxias Norte 225, Pirassununga, SP 13635-900, Brazil.

${ }^{4}$ Departamento de Zootecnia e Medicina Veterinária, FZEA-USP, Av. Duque de Caxias Norte 225, Pirassununga, SP 13635-900, Brazil.

${ }^{5}$ Departamento de Zootecnia, FZEA-USP, Av. Duque de Caxias Norte 225, Pirassununga, SP 13635-900, Brazil. *Corresponding author: rfranzol@usp.br
}

dores de mastites subclínicas em búfalas foram isolados desde 20 amostras de leite de búfalos de quatro granjas leiteiras localizadas na região central do Estado de São Paulo, Brasil, através dos testes contagem de células somáticas (CCS), contagem padrão em placas (CPP), provas bioquímicas, reações de PCR e perfil antimicrobiano. A CCS apresentou uma mediana de $721.000 \mathrm{cel} / \mathrm{mL}$ no leite, indicando presença de mastite subclínica. A média geral de CPP foi de $1,8 \times 10^{4} \mathrm{UFC} / \mathrm{mL}$. Os microrganismos com maior frequência de isolamento segundo os testes bioquímicos foram: Staphylococcus epidermidis (17\%), Staphylococcus aureus (15\%), Bacillus spp. (14\%), Acinetobacter spp. (12,5\%); frequência intermediaria: Pseudomonas aeruginosa (9,5\%); Shigella flexneri (7,0\%), Streptococcus spp. (5,5\%), Corynebacterium spp. (5,0\%), Escherichia coli (4,5\%), Serratia 
marcescens $(4,0 \%)$, Stenotrophomonas maltophilia $(4,0 \%)$, e baixa incidência: Klebsiella rhinoscleromatis (0,5\%), Klebsiella ozaenae (0,5\%), Tatumella ptyseos $(0,5 \%)$, Enterobacter cloacae $(0,5 \%)$. A análise molecular indicou que as amostras positivas pelo método de cultura dos gêneros Staphylococcus, Streptococcus e Escherichia coli foram positivas por PCR. Para S. aureus e S. epidermidis os maiores percentuais de sensibilidade observados foram gentamicina $(100 \%)$ e vancomicina (100\%); para o gênero Streptococcus à gentamicina e oxacilina e para E. coli à ampicilina. Este resultados podem ajudar no controle e tratamento da mastite subclínica em búfalos e contribuir para melhorar a eficiência e qualidade do leite produzido.

TERMOS PARA INDEXAÇÃO: Susceptibilidade antimicrobiano, bactérias, mastite subclínica, búfalos, antibióticos, contagem de células somáticas, leite.

\section{INTRODUCTION}

The buffalo milk production is a highly important activity in many countries, among which are highlighted Asian countries, Italy and Brazil (Bernardes 2007). In Brazil, the buffalo has been exploited for milk and meat, but the main economic activity is the dairy industry, especially the mozzarella cheese produced exclusively with buffalo milk (Andrighetto et al. 2005, Bernardes 2007, Araujo et al. 2012). Buffalo milk has a great potential for commercial production due mainly contain particular physicochemical characteristics with high total solids, fat and protein (Amaral et al. 2005).

The importance of identifying the aspects related to the health of the mammary gland and milk products of buffaloes has been highlighted in the world literature as in Brazil (Medeiros et al. 2011), India (Tiwari et al. 2011), Pakistan (Hussain et al. 2013), Nepal (Dhakal et al. 2007), Italy (Fagiolo \& Lai 2007) and Germany (Braun \& Preuss 2007). Mastitis is an inflammation of the mammary gland parenchyma due to an infectious process predominantly caused by many microorganisms, particularly bacteria, and may also be involved fungi and yeast (Baloch et al. 2011). The effective and accurate diagnosis is extremely important to control this severe disease in buffalo (Viana et al. 2010). However, the absence of macroscopic changes in the tissues or secretions in cases of subclinical mastitis, does not allow the identification of infected mammary quarters before milking, once routine diagnostic methods include only physical examination, and fluid secretion (Bonini Pardo et al. 2007). Several factors have been identified as predisposing to subclinical mastitis in buffalo, as level of milk production, body weight, calving period, udder type and hygiene conditions for milking (Hussain et al. 2013).

Along the lack of information on the buffalo species, the same animal management techniques for cattle milk production are used for the control of mastitis in buffalo milk production, resulting in lack of success since they have peculiar habits of each ruminant species (Carvalho et al. 2007, Medeiros et al. 2011). Indeed, most of mastitis prevalence was found in cow's milk (32\%) than in buffalo milk (22\%) (Khan et al. 2013). Thus, subclinical mastitis unfortunately has not been diagnosed with frequency and consequently its etiology has not been widely investigated (Fagiolo \& Lai 2007). In addition, Brazilian literature has presented a considerable number of publications about the buffalo mastitis, but when compared to the number of papers on bovine mastitis is small. A fact that needs more research efforts because buffalo has attracted growing interest of breeders and research institutions as an alternative for dairy farming (Langoni et al. 2001, Jorge et al. 2005, Medeiros et al. 2011).

The objective of this work was the isolation and phenotypic characterization of the main microorganisms that cause mastitis subclinical in buffaloes (Bubalus bubalis) raised in four dairy farms located in central region of Sao Paulo state, Brazil, as well as the molecular characterization and evaluation of bacterial sensitivity profile for the isolated species.

\section{MATERIALS AND METHODS}

This study was carried out at four commercial buffalo farms in the central region of São Paulo State, Brazil, using animals reared in a loose housing system with supplementation of concentrated ration according to the stage of lactation. Water and mineral supplementation were available ad libitum. The procedures involved in this experiment were approved by Comissão de Ética no Uso de Animais (CEUA/FZEA) (Protocol \#13.1.2338.74.7). In order to select buffaloes more prone to subclinical mastitis, sanitary control data carried out by the property were evaluated and Somatic Cell Count test (SCC) of all of the female buffaloes in the herd at previous month were taken in account. Thus, milk samples were selected from twenty animals that showed SCC values above to 200,000 cells/mL (Dhakal 2006). Selected animals were dairy buffaloes of Murrah breed, in the second or third stage of lactation, with average production of $7 \mathrm{~kg}$ of milk/animal/day, in two daily milking. After the physical examination of the mammary gland, twenty milk samples were collected by combining the four quarters of the mammary in duplicate with all necessary hygiene, properly identified and packed in insulated boxes with ice packs.

One of the samples, collected in a bottle containing Bromopol (Microtabs ${ }^{\circledR}$ ) was designed to determine the SCC by flow cytometry using Somacount 500 equipment. The second sample was collected aseptically for microbiological analysis and antimicrobial susceptibility testing. For the Standard Plate Count (SPC), the milk samples were diluted in sterile peptone water solution (Hime$\mathrm{dia}^{\circledR}$, India) at $0.1 \%(\mathrm{w} / \mathrm{v})$. Aliquot $0.1 \mathrm{~mL}$ of each dilution $\left(10^{-1}\right.$, $10^{-2}, 10^{-3}, 10^{-4}$ and $10^{-5}$ ) was inoculated into Brain Heart Infusion agar (BHI - Difco, USA) and incubated at $37^{\circ} \mathrm{C}$ under aerobic conditions for 48 hours. Then, the read of the plates was carried out after the incubation. Ten colonies with different characteristics were picked up randomly per animal and seeded by exhaustion for the isolation of colonies in different culture media: blood agar (Acumedia $^{\circledR}$, USA), Eosin Methylene Blue Agar (Himedia ${ }^{\circledR}$, India), Mannitol Agar (Himedia ${ }^{\circledR}$, India) and MacConkey Agar (Himedia ${ }^{\circledR}$, India). The microorganism pure of the respective boards were identified based on Gram stain, morphology and macroscopic characteristics.

Biochemical tests were subsequently carried out in accordance with bacterial groups identified in previous tests. Strains of Staphylococcus spp. were submitted to the free coagulase tests (Plasma Coagulase EDTA, Coagu LB - Laborclin, Brazil), DNase (DNase Agar - Difco ${ }^{\circledR}$, USA), latex agglutination particles (Laborclin, Brazil) and catalase test. The tests of glucose fermentation 
(aerobiosis) and mannitol (aerobiosis and anaerobiosis) were performed according (Macfaddin 1980) and isolates classified in accordance with (Baird-Parker 1990).

Gram negative bacteria isolated were identified using Bactray Kit I, II and III ${ }^{\circledR}$ of biochemical identification (Laborclin, Brazil). The genus Bacillus was featured on nutrient agar by the formation of colonies rounded, smooth and irregular border with creamy consistency, gram stain and rod shape with catalase and oxidase test. The bacteria whose colonies had become small, round, whitish or creamy, with rough surface, measuring 1 to $2 \mathrm{~mm}$ in diameter, gram-positive rods, absence of hemolysis on blood agar, catalase production, were classified as Corynebacterium spp. Tests for Streptococcus genus identification included absence of catalase production, growth in Bile Agar Esculin (Himedia ${ }^{\circledR}$, India), type of hemolysis on blood agar ( $\alpha, \beta$ and $\gamma$ hemolytic) with $5 \%$ defibrinated blood sheep and tolerance to tellurite.

The molecular characterization of isolated Staphylococcus spp., Streptococcus spp. and E. coli were performed according to Shome et al. (2011) with some modifications. Isolated microorganisms of cultures incubated for 18 hours at $37^{\circ} \mathrm{C}$ in Brain Heart Infusion agar (BHI - Difco, USA) were replicated in one $\mathrm{mL}$ of broth in $\mathrm{BHI}$ and incubated at $37^{\circ} \mathrm{C}$ under stirring for 24 hours. After centrifugation at $10,000 \mathrm{x}$ g for $10 \mathrm{~min}$, the supernatant was discarded and the pellet was solubilized in $100 \mathrm{uL}$ of MilliQ water, homogenized and incubated at $95^{\circ} \mathrm{C}$ for $10 \mathrm{~min}$. Then the wells were centrifuged at $12,000 \mathrm{xg}$ for $2 \mathrm{~min}$ at room temperature, and the supernatant was used as a substrate for PCR reactions (Fang \& Hedin 2003). The concentration of genomic DNA was determined using genequant pro RNA/DNA calculator, GE Healthcare, EUA and stored at $20^{\circ} \mathrm{C}$ until use. Six pairs of primers were selected for amplification of genomic fragments of bacterial strains belonging to the genera Staphylococcus (23S rRNA, sodA, rdr and gap genes), three pairs of primers to the genera Streptococcus (16S rRNA and cpn60 genes), and one pair of primers to the E. coli (phoA gene) (Shome et al. 2011) (Table 1).

For the PCR reactions were used GoTaq ${ }^{\circledR}$ Green Master Mix kit (Promega Corporation, USA) according to the manufacturer's recommendations. Briefly, the PCR reaction has consisted of a solution containing around 200ng of DNA; $12.5 \mu \mathrm{L}$ of $\mathrm{GoTaq}^{\circledR}$ Colorless Master Mix 2X; $0.4 \mu \mathrm{M}$ of each specific sense primer; $0.4 \mu \mathrm{M}$ of each specific antisense primer and $9.5 \mu \mathrm{L}$ of nuclease- free water (GE Healthcare, USA) totaling $25.0 \mu \mathrm{L}$. The thermocycling protocol (Swift ${ }^{\circledR}$ MaxPro Thermal Cycler, Esco Technologies Inc., USA) was: initial denaturation at $94^{\circ} \mathrm{C}$ for $5 \mathrm{~min}$, and 30 cycles of $94^{\circ} \mathrm{C}$ for $30 \mathrm{sec}, 60^{\circ} \mathrm{C}$ for $30 \mathrm{sec}$ and $72^{\circ} \mathrm{C}$ for $45 \mathrm{sec}$ and final extension at $72^{\circ} \mathrm{C}$ for $10 \mathrm{~min}$ (Shome et al. 2011). The resulting amplicons were subjected to electrophoresis in agarose gel $2 \%$ in Tris-acetate/EDTA buffer (TAE $1 \mathrm{X}$ ) in $8 \mu \mathrm{L}$ volume per sample, adding a $2 \mu \mathrm{L}$ of a solution containing $10 \mathrm{mM}$ Tris- $\mathrm{HCl}$ (pH 7.5), 50mM EDTA ( $\mathrm{pH}$ 8.0), 0.03\% (w/v) bromophenol blue, $0.03 \%$ xylene cyanol FF and $15 \%$ Ficoll $^{\circledR} 400$ (Blue / Orange Loading Dye, 6X, Promega, USA).

Subsequently, the gel was subjected to staining solution of SYBR $^{\circledR}$ Gold nucleic acid gel stain (Life Technologies, USA) and observed under UV light, using a photo documentation system L-Pix ST and L-PixImage software (Loccus Biotechnology, Brazil). The size of the fragments was determined by comparison of the pattern of electrophoretic migration of a molecular weight marker $100 \mathrm{pb}$ (GE Healthcare, USA). The standard strains Staphylococcus aureus ATCC 29213, Staphylococcus epidermidis ATCC 12228, Escherichia coli ATCC 43895 were used as controls of the reactions.

The antimicrobial profile was determined using eight isolates of $S$. aureus, S. epidermidis, S. agalactiae and E. coli previously identified in biochemical and molecular tests. After growing in $\mathrm{BHI}$ incubated at $37^{\circ} \mathrm{C}$ for 24 hours, the bacterial cultures were plated on Mueller Hinton Agar (Himedia ${ }^{\circledR}$, India) for carrying out the antibiograms, through the simple method disk, according to the technique described by Bauer (1966). The following antibiotics and dosages for Staphylococcus and Streptococcus genera were used: cefepime $(30 \mu \mathrm{g})$ clindamycin $(2 \mu \mathrm{g})$, erythromycin $(15 \mu \mathrm{g})$, gentamicin $(10 \mu \mathrm{g})$, oxacillin $(1 \mu \mathrm{g})$, penicillin $\mathrm{G}(10 \mu \mathrm{g})$, rifampicin $(34 \mu \mathrm{g})$, sulphazotrim $(25 \mu \mathrm{g})$, tetracycline $(30 \mu \mathrm{g})$ and vancomycin $(30 \mu \mathrm{g})$ and for E. coli: ampicillin $(10 \mu \mathrm{g})$, amoxicillin + clavulanate $(30 \mu \mathrm{g})$, ceftazidime $(30 \mu \mathrm{g})$, cefepime $(30 \mu \mathrm{g})$, cefoxitin $(30 \mu \mathrm{g})$, cefuroxime $(30 \mu \mathrm{g})$, gentamicin $(10 \mu \mathrm{g})$, meropenem $(10 \mu \mathrm{g})$, cephalothin $(30 \mu \mathrm{g})$ and Trimethoprim + sulphazotrim $(25 \mu \mathrm{g})$. The plates were incubated for 24 hours at $37^{\circ} \mathrm{C}$. After reading the halos formed around the discs, we determined the sensitivity profile and resistance of isolated according to the manual for antibiogram diffusion in Kirby-Bauer disk (Laborclin, Brazil).

Table 1. Sequence of primers used in the confirmation of the most frequent microorganisms in the isolation of subclinical mastitis in buffaloes

\begin{tabular}{|c|c|c|c|c|c|}
\hline Microorganism & Primer & Gene & Orientation & Sequence of primer $5^{\prime}-3^{\prime}$ & Product $(\mathrm{pb})$ \\
\hline \multirow[t]{2}{*}{ Staphylococcus aureus } & SAS2F & $23 S$ & sense & AGCGAGTCTGAATAGGGCGTTT & 894 \\
\hline & SAS2R & rRNA & antisense & CCСATCACAGCTCAGCCTTAAC & \\
\hline \multirow{2}{*}{ Staphylococcus chromogenes } & SCHS1F & sodA & sense & GCGTACCAGAAGATAAACAAACTC & 222 \\
\hline & SCHS1R & & antisense & CATTATTTACAACGAGCCATGC & \\
\hline \multirow[t]{2}{*}{ Staphylococcus haemolyticus } & SHS1F & $\operatorname{sod} A$ & sense & CAAATTAAATTCTGCAGTTGAGG & 214 \\
\hline & SHS1R & & antisense & AGAGCCCATTGTTCTTTGA & \\
\hline \multirow[t]{2}{*}{ Staphylococcus epidermidis } & SERF & $r d r$ & sense & AAGAGCGTGGAGAAAAGTATCAAG & 130 \\
\hline & SERR & & antisense & TCGATACCATCAAAAAGTTGG & \\
\hline \multirow[t]{2}{*}{ Staphylococcus sciuri } & SSCGF & gap & sense & GATTCCGCGTAAACGGTAGAG & 306 \\
\hline & SSCGR & & antisense & СATCATTTAATACTTTAGCCATTG & \\
\hline \multirow[t]{2}{*}{ Staphylococcus simulans } & SSMF & gap & sense & AGCTTCGTTTACTTCTTCGATTGT & 472 \\
\hline & SMR & & antisense & AAAAGCACACAAGCTCACATTGAC & \\
\hline \multirow[t]{2}{*}{ Streptococcus agalactiae } & STAGF & $16 S$ & sense & GCTAATACCGCATAAGAGTAATTAAC & 317 \\
\hline & STAGR & rRNA & antisense & GGTAGATTTTCCACTCCTACСАA & \\
\hline \multirow[t]{2}{*}{ Streptococcus dysgalactiae } & STDGF & $16 S$ & sense & GGGAGTGGAAAATCCACCAT & 572 \\
\hline & STAGR & $r R N A$ & antisense & AAGGGAAAGCCTATCTCTAGACC & \\
\hline \multirow[t]{2}{*}{ Streptococcus uberis } & STUBF & cpn60 & sense & TCGCGGTATTGAAAAAGCAACAT & 400 \\
\hline & STUBR & & antisense & TGCAATAATGAGAAGGGGACGAC & \\
\hline \multirow{2}{*}{ Escherichia coli } & ECPF & phoA & sense & GGTAACGTTTCTACCGCAGAGTTG & 468 \\
\hline & ECPR & & antisense & CAGGGTTGGTACACTGTCATTACG & \\
\hline
\end{tabular}




\section{RESULTS}

The average Somatic cell count was 721,000 cells/mL of milk (minimum: 205,000, maximum: 2.264 million), indicating the presence of subclinical mastitis. All positive -samples by culture method were also positive by PCR that confirmed the identity of the Staphylococcus aureus, S. epidermidis and E. coli species with amplimers electrophoretic pattern compatible with the described species. Two isolates have showed an amplification product ( $500 \mathrm{bp}$ ) specific to Streptococcus dysgalactiae and eight isolates have showed an amplification product of $300 \mathrm{pb}$ in PCR for Streptococcus. agalactiae.

All twenty samples showed bacterial growth in the BHI agar. The overall average of standard plate count obtained in this study was $1.8 \times 10^{4} \mathrm{CFU} / \mathrm{mL}$. Two hundred isolates recovered from milk samples culture were submitted to phenotypic and biochemical characterization (Table 2). S. epidermidis $(17 \%)$ was the most frequently isolated organism, followed by S. aureus (15\%). As further relates to Gram-positive pathogens, there was high isolation Bacillus spp. in buffalo milk (14\%). However, bacteria of the genus Streptococcus spp. had a lower frequency of isolation $(5.5 \%)$ as well as the gram negative bacteria E. coli $(4.5 \%)$.

Table 2. Bacteria number and frequency of isolates (\%) in buffalo milk samples with subclinical mastitis

\begin{tabular}{lc}
\hline Microrganism & Number Frequency (\%) \\
\hline Staphylococcus epidermidis & $34(17.0 \%)$ \\
Staphylococcus aureus & $30(15.0 \%)$ \\
Bacillus spp. & $28(14.0 \%)$ \\
Acinetobacter spp. & $25(12.5 \%)$ \\
Pseudomonas aeruginosa & $19(9.5 \%)$ \\
Shigella flexneri & $14(7.0 \%)$ \\
Streptococcus spp. & $11(5.5 \%)$ \\
Corynebacterium spp. & $10(5.0 \%)$ \\
Escherichia coli & $9(4.5 \%)$ \\
Serratia marcescens & $8(4.0 \%)$ \\
Stenotrophomonas maltophilia & $8(4.0 \%)$ \\
Klebsiella rhinoscleromatis & $1(0.5 \%)$ \\
Klebsiella ozaenae & $1(0.5 \%)$ \\
Tatumella ptyseos & $1(0.5 \%)$ \\
Enterobacter cloacae & $1(0.5 \%)$ \\
Isolation total & 200
\end{tabular}

Table 3. In vitro susceptibility profile of Staphylococcus aureus, Staphylococcus epidermidis and Streptococcus spp. isolated from buffalo milk samples with subclinical mastitis

\begin{tabular}{|c|c|c|c|c|c|c|}
\hline \multirow[t]{3}{*}{ Antimicrobian } & \multicolumn{6}{|c|}{ Sensibility profile } \\
\hline & \multicolumn{2}{|c|}{$\begin{array}{c}\text { Staphylococcus } \\
\text { aureus }\end{array}$} & \multicolumn{2}{|c|}{$\begin{array}{l}\text { Staphylococcus } \\
\text { epidermidis }\end{array}$} & \multicolumn{2}{|c|}{$\begin{array}{l}\text { Streptococcus } \\
\text { spp. }\end{array}$} \\
\hline & $\stackrel{x}{N}$ & $\%$ & $\mathrm{~N}$ & $\%$ & $\mathrm{~N}$ & $\%$ \\
\hline Gentamicin $(10 \mu \mathrm{g})$ & $8 / 8$ & 100.0 & $8 / 8$ & 100.0 & $8 / 8$ & 100.0 \\
\hline Vancomycin $(30 \mu \mathrm{g})$ & $8 / 8$ & 100.0 & $8 / 8$ & 100.0 & $2 / 8$ & 25.0 \\
\hline Clindamycin $(2 \mu \mathrm{g})$ & $4 / 8$ & 50.0 & $4 / 8$ & 50.0 & $2 / 8$ & 25.0 \\
\hline Erythromycin $(15 \mu \mathrm{g})$ & $4 / 8$ & 50.0 & $4 / 8$ & 50.0 & $2 / 8$ & 25.0 \\
\hline Penicillin G $(10 \mu \mathrm{g})$ & $2 / 8$ & 25.0 & $3 / 8$ & 37.5 & $1 / 8$ & 12.5 \\
\hline Sulphazotrim $(25 \mu \mathrm{g})$ & ) $4 / 8$ & 50.0 & $4 / 8$ & 50.0 & $6 / 8$ & 75.0 \\
\hline Oxacillin $(1 \mu \mathrm{g})$ & $4 / 8$ & 50.0 & $4 / 8$ & 50.0 & $8 / 8$ & 100.0 \\
\hline Cefepime $(30 \mu \mathrm{g})$ & $4 / 8$ & 50.0 & $4 / 8$ & 50.0 & $2 / 8$ & 25.0 \\
\hline Tetracycline $(30 \mu \mathrm{g})$ & $2 / 8$ & 25.0 & $3 / 8$ & 37.5 & - & - \\
\hline Rifampicin $(34 \mu \mathrm{g})$ & $4 / 8$ & 50.0 & $4 / 8$ & 50.0 & $2 / 8$ & 25.0 \\
\hline
\end{tabular}

$\overline{\mathrm{N}}=$ evaluated number of microorganisms.
Table 4. In vitro susceptibility profile of Escherichia coli isolated from buffalo milk samples with subclinical mastitis

\begin{tabular}{lcc}
\hline Antimicrobian & \multicolumn{2}{c}{$\begin{array}{c}\text { Sensibility profile of } \\
\text { Escherichia coli }\end{array}$} \\
\cline { 2 - 3 } & $\mathrm{N}$ & $\%$ \\
\hline Cephalothin $(30 \mu \mathrm{g})$ & $6 / 8$ & 75.0 \\
Ampicillin $(10 \mu \mathrm{g})$ & $8 / 8$ & 100.0 \\
Meropenem $(10 \mu \mathrm{g})$ & $6 / 8$ & 75.0 \\
Trimethoprim-sulfamethoxazole $(25 \mu \mathrm{g})$ & $6 / 8$ & 75.0 \\
Cefuroxime $(30 \mu \mathrm{g})$ & $6 / 8$ & 75.0 \\
Amoxicillin + clavulanate $(30 \mu \mathrm{g})$ & $5 / 8$ & 62.5 \\
Cefoxitin $(30 \mu \mathrm{g})$ & $6 / 8$ & 75.0 \\
Cefepime $(30 \mu \mathrm{g})$ & $6 / 8$ & 75.0 \\
Ceftazidime $(30 \mu \mathrm{g})$ & $6 / 8$ & 75.0 \\
Gentamicin $(10 \mu \mathrm{g})$ & $4 / 8$ & 50.0
\end{tabular}

$\mathrm{N}=$ evaluated number of microorganisms.

The study of bacterial sensitivity (Table 3 ) has showed that $S$. aureus and $S$. epidermidis bacteria were more sensitive to antibiotics gentamicin $(100 \%)$ and vancomycin (100\%). For the genus Streptococcus, gentamicin and oxacillin were the best action antibiotics, followed by sulphazotrim. In contrast, gentamicin was a less effective antimicrobial (50\%) for Escherichia coli isolates (Table 4).

\section{DISCUSSION}

The higher average obtained from the SCC $(721,000$ cells/ $\mathrm{mL}$ ) was expected, since the sampling was restricted to buffaloes that had high SCC in order to obtain samples with microorganisms that may cause subclinical mastitis. It was high compared to average values of 63,000 cells $/ \mathrm{mL}$ observed in 2693 buffalo milk samples belonging to a single herd from state of Sao Paulo (Cerón-Muñoz et al. 2002) and 63,380 cells/mL mean value identified in lactating buffaloes also in Brazil (Jorge et al. 2005). Subclinical mastitis in buffalo milk samples was previously described with SCC greater than 200,000 cells/mL and positive bacterial growth in culture in $21.7 \%(52 / 200)$ of the evaluated animals (Dhakal 2006). High SCC has been obtained in crossbred Murrah buffaloes, with values of 171,000 cells/mL for animals without mastitis, 799,000 cells/mL for animals with subclinical mastitis and 6,039,000 cells/mL with clinical mastitis (Dhakal et al. 2008).

The most often agents isolated in the samples Staphylococcus epidermidis (17\%) and S. aureus (15\%) (Table 2) were similar to those obtained in 49 adult Murrah buffalo at different stages of lactation in herds from state of Pernambuco, Brazil (Oliveira et al. 2004). In that study, the Staphylococcus genus was considered the main etiological agent, being of great epidemiological importance in buffalo mastitis. Indeed, the genus Staphylococcus has been predominantly isolated in samples from buffalo Murrah crossbred with subclinical mastitis (Dhakal et al. 2008) and clinical mastitis (Pizauro et al. 2014). Khan and Muhammad (2005) obtained similar prevalence for microbiological analysis in milk samples of buffalos from Pakistan: Staphylococcus spp. (45\%), Streptococcus spp. (23\%) and Bacillus spp. (14\%). However, Khan et al. (2013) observed a greater prevalence of $S$. aureus in cow milk samples (90\%) than in buffalo milk (84\%). Langoni et al. (2001) observed 
prevalence of S. epidermidis (30.1\%) and S. aureus (4.8\%) in buffaloes with mastitis in São Paulo, Brazil. Other studies have also identified a high prevalence of $S$. epidermidis (Tenhagen et al. 2009, Sampimon et al. 2009, Pankaj et al. 2013), indicating the importance of this group of microorganisms which are commonly described as lower prevalence of pathogens in the case of mastitis. In addition, S. epidermidis is a component of the normal flora of the skin of the udder and its prevalence, as observed in this study may be a result of poor hygienic practices for milking.

Acinetobacter was isolated with a frequency also considered high of $12.5 \%$ in this study. Similar results were found in cows with clinical mastitis and milk samples with mastitis in Korea (Nam et al. 2009, 2010, Gurung et al. 2013). The association of this bacterium with subclinical mastitis in buffaloes presents a new challenge for the treatment and control of disease. There is need for further studies to evaluate its role as a pathogen potential and identify possible sources of contamination.

The percentage of Pseudomonas aeruginosa isolated, can be related to the occurrence of the contamination in milk during and/or after milking, such as contaminated water used for washing the teat, cleaning and during intramammary therapy (Fernandes et al. 2009, Langoni et al. 2009).

The incidence of Bacillus spp. observed (14\%) is found within a wide occurrence in buffalo milk samples ranging from 2.4 to $32.4 \%$ (Langoni et al. 2001, Oliveira et al. 2004, Dhakal et al. 2008). This level of detection may differ according to the type of sample of milk, herd and region. This kind of bacteria is widely distributed in soil, water, air, feces and vegetation.

Although Streptococcus are considered less frequent agents of mastitis, as also obtained in this study, these opportunistic pathogens are widespread in the environment and can be found on the ground, water and manure. However, some studies have identified the Streptococcus spp. as the major etiologic agent isolated from buffalo subclinical mastitis (Fagiolo \& Lai 2007).

Low frequency of $E$. coli was observed in this study $(4.5 \%)$ being in agreement with the data obtained by Saini et al. (1994) that observed lower frequency of microorganisms E. coli (12.9\%) in buffalo milk samples from Punjab, India. Moreover, Kumar (2009) observed buffalo milk samples with high incidence of mastitis E. coli (30\%).

Other species of bacteria as Lactococcus garvieae and Enterococcus gallinarum have been isolated from milk samples of buffalo subclinical mastitis (Vianni \& Lazaro 2003). Arcobacter species also has considered an important source of bacteria in cow and buffalo milk with risk to public health (Yesilmen et al. 2014).

Conventional bacterial culture is relatively slow performance, since incubation of primary cultures often requires 48 hours (or 72 hours) to be completed, and additional confirmatory tests are relatively time-consuming. The PCR assay for the identification of microorganisms in milk samples with mastitis require an analysis time of 3 to 4 hours. In the case of subclinical mastitis such quick results may allow the identification of animals with this disease and indicate the treatment, while optimizing the results with appropriate use of antibiotics and reduce the indiscriminate usage. Moreover, PCR has been shown to be more sensitive and specific for the diagnosis of microorganisms in subclinical mastitis than conventional culturing technique (Shahzad et al. 2013).

Gentamicin was the antibiotic of choice for Staphylococcus and Streptococcus bacteria (Table 3) partially agreeing with the findings of Cunha et al. (2006) who observed a wide gentamicin action with high antimicrobial efficacy (97.98\%) on various bacteria and association including Staphylococcus spp., Streptococcus spp. and E. coli. However, gentamicin was one of the less effective antimicrobial (50\%) for E. coli isolates (Table 4). But, this finding agrees with the results of Costa (2008) who observed that aminoglycosides and sulfonamides were the antimicrobials less effective for $E$. coli, highlighting the sensitivity percentage of $46.2 \%$ and $41.8 \%$ for gentamicin and neomycin, respectively.

For the genus Streptococcus, gentamicin and oxacillin were the best action antibiotics, followed by sulphazotrim (Table 3), confirming the data of Langoni et al. (2001) who have demonstrated a better efficiency of gentamicin (96\%) and oxacillin (95\%) on the isolated agents with more frequency: Corynebacterium bovis, Staphylococcus epidermidis and Streptococcus agalactiae.

The somatic cell count and standard plate count can perform an assessment of the health status of the buffalo mammary gland with subclinical mastitis and emphasize the importance of a normative specific for buffalo that allows the control and inspection of milk, since the parameters used for cattle may not be suitable for monitoring mastitis in buffalo herds.

\section{CONCLUSION}

This study highlights the importance of some pathogens involved subclinical mastitis in buffaloes and the possibility of specific antimicrobial use in the control and treatment of this serious problem, promoting increased quality and milk production with effective reduction of production costs and improvement in health foods.

Acknowledgements.- Credit to Coordenação de Aperfeiçoamento de Pessoal de Nível Superior (CAPES-Brazil) for financial support and to farmers of buffalo for their interest in scientific research to improve the quality of milk products.

Conflict of interest statement.- The authors have no competing interests.

\section{REFERENCES}

Amaral F.R., Carvalho L.B., Silva N. \& Brito J.R.F. 2005. Qualidade do leite de búfalas: composição. Revta Bras. Reprod. Anim. 29:106-110.

Andrighetto C., Jorge A.M., Gomes M.I.F.V., Hoch A. \& Piccinin A. 2005. Effect of monensin on milk production and composition, production of mozzarela cheese and body condition score of Murrah buffalo cows. Revta Bras. Zootec. 34:641-649.

Araujo K.B.S., Rangel A.H.N., Fonseca F.C.E., Aguiar E.M., Simplicio A.A., Novaes L.P. \& Lima Júnior D.M. 2012. Influence of the year and calving season on production, composition and mozzarella cheese yield of water buffalo in the State of Rio Grande do Norte, Brazil. Ital. J Anim. Sci. 11:87-91. 
Baird-Parker A.C. 1990. The staphylococci: an introduction. J. Appl. Microbiol. Symp. Suppl. 69:1S-8S.

Baloch H., Rind R., Kalhoro D.H. \& Kalhoro A.B. 2011. Study on the incidence of mastitis in buffaloes caused by bacterial species. Pak. J. Agri., Agril. Engg., Vet. Sci. 27:83-93.

Bauer A.W., Kirby E., Sherris E.M. \& Turk M. 1966. Antibiotic by standarized single disk method. Am. J. Clin. Pathol. 45:493-496.

Braun P.G. \& Preuss S.E. 2007. Microbial quality of water buffalo milk and milk products in Germany. Milchwissenschaft 62:276-278.

Bernardes 0. 2007. Buffaloes breeding in Brasil. Ital. J. Anim. Sci. 6:162167.

Bonini Pardo R., Mendoza-Sánchez G., Nader Filho A., Santos T.A.B., Langoni H., Tonhati H., Ferreir E.B.S., Ravena D.L., Oliveira M.E.A. \& Sturion D.J. 2007. Microbiological evaluation of milk samples positive to California Mastitis Test in dairy buffalo cows (Buballus bubalis). Ital. J. Anim. Sci. 6:884-887.

Carvalho L.B., Amaral F.R., Brito M.A.V.P., Lange C.C., Brito J.R.F. \& Leite R.C. 2007. Contagem de células somáticas e isolamento de agentes causadores de mastite em búfalas (Bubalus bubalis). Arq. Bras. Med. Vet. Zootec. 59:242-245

Cerón-Muñoz M., Tonhati H., Duarte J., Oliveira J., Muñoz-Berrocal M. \& Jurado-Gámez H. 2002. Factors affecting somatic cell counts and their relations with milk and milk constituent yield in buffaloes. J. Dairy Sci. 85:2885-2889.

Costa G.M. 2008. Mamite bovina em rebanhos leiteiros da região sul do Estado de Minas Gerais. Tese de Doutorado, Escola de Veterinária, Universidade Federal de Minas Gerais, Belo Horizonte, MG. 123p.

Cunha A.P., Silva L.B.G., Pinheiro Júnior J.W., Silva D.R., Oliveira A.A.F., Silva K.P.C. \& Mota R.A. 2006. Perfil de sensibilidade antimicrobiana de agentes contagiosos e ambientais isolados de mastite clínica e subclínica de búfalas. Arqs Inst. Biológico, São Paulo, 73:17-21.

Dhakal I.P. 2006. Normal somatic cell count and subclinical mastitis in Murrah buffaloes. J. Vet. Med. B 53:81-86.

Dhakal I.P., Dhakal P., Koshihara T. \& Nagahata H. 2007. Epidemiological and bacteriological survey of buffalo mastitis in Nepal. J. Vet. Med. Sci. 69:1241-1245.

Dhakal I.P., Neupane M. \& Nagahata H. 2008. Evaluation of direct and indirect measures of quarter milk from crossbred buffaloes. Anim. Sci. J. 79:628-633

Fagiolo A. \& Lai O. 2007. Mastitis in buffalo. Ital. J. Anim. Sci. 6:200-206.

Fang H. \& Hedin G. 2003. Rapid screening and identification of methicillin-resistant Staphylococcus aureus from clinical samples by selective-broth and real-time PCR assay. J. Clin. Microbiol. 41:2894-2899.

Fernandes M.C., Ribeiro M.G., Siqueira A.K., Salerno T., Lara G.H.B. \& Listoni F..P. 2009. Surto de mastite bovina causada por linhagens de Pseudomonas aeruginosa multirresistentes aos antimicrobianos. Arq. Bras. Med. Vet. Zootec. 61:745-748.

Gurung M., Nam H.M., Tamang M.D., Chae MH., Jang G.C., Jung S.C. \& Lim S.K. 2013. Prevalence and antimicrobial susceptibility of Acinetobacter from raw bulk tank milk in Korea. J. Dairy Sci. 96:1997-2002.

Hussain R., Javed M.T., Khan A. \& Muhammad G. 2013. Risks factors associated with subclinical mastitis in water buffaloes in Pakistan. Trop. Anim. Health Prod. 45:1723-1729.

Jorge A.M., Andrighetto C., Strazza M.R.B., Correa R.C., Kasburgo D.G., Piccinin A., Victoria C. \& Domingues P.F. 2005. Correlation between the California Mastitis Test (CMT) and somatic cells count on milk from Murrah buffalo cows. Revta Bras. Zootec. 34:2039-2045.

Khan J.M., Rasool M.H., Arshad M., Rahman S.U., Tahir M.F., Aslam B., Jing W., Jun Z. \& Ghani M. 2013. Comparative Evaluation of Leukotoxic Activities of Indigenous Staphylococcus aureus Isolates from Subclinical and Clinical Mastitic Milk Samples of Buffalo and Cattle. Open Vet. J. 7:24-27.

Khan A.Z. \& Muhammad G. 2005. Quarter-wise comparative prevalence of mastitis in buffaloes and crossbred cows. Pakistan Vet. J. 25:9-12.

Kumar P.A. 2009. Evaluation of PCR test for detecting major pathogens of bubaline mastitis directly from mastitis milk samples of buffaloes. Trop. Anim. Health Prod. 41:1643-1651.

Langoni H., Sakiyama D.T.P., Guimarães F.F., Menozzi B.D. \& Da Silva R.C. 2009. Aspectos citológicos e microbiológicos do leite em propriedades no sistema orgânico de produção. Pesq. Vet. Bras. 29:881-886.

Langoni H., Domingues P.F., Molero Filho J.R. \& Baldini S. 2001. Etiologia e sensibilidade bacteriana da mastite subclínica em búfalos (Bubalus bubalis). Ars Vet. 17:213-217.

Macfaddin J.F. 1980. Biochemical Tests for Identification of Medical Bacteria. Williams and Wilkins, Baltimore, USA.

Medeiros E.S., Freitas M.F.L., Saukas T.N., Azevedo S.S., Pinheiro Junior J.W., Brandespim D.F., Neto O.L.D. \& Mota R.A. 2011. Risk factors associated with buffalo mastitis in the Brazilian Northeast. Pesq. Vet. Bras. 31:499504.

Nam H.M., Lim S.K., Kang H.M., Kim J.M., Moon J.S., Jang K.C., Kim J.M., Joo Y.S. \& Jung S.C. 2009. Prevalence and antimicrobial susceptibility of gram-negative bacteria isolated from bovine mastitis between 2003 and 2008 in Korea. J. Dairy Sci. 92:2020-2026.

Nam H.M., Lim S.K., Kim J.M., Joo Y.S., Jang K.C. \& Jung S.C. 2010. In vitro activities of antimicrobials against six important species of gram-negative bacteria isolated from raw milk samples in Korea. Foodborne Pathog. Dis. 7:221-224.

Oliveira M.V.V., Mota R.A., Oliveira A.A.F., Meirelles F.S. \& Silva F.F. 2004. Utilização do whiteside modificado e california mastites test no diagnóstico da mastite subclínica em búfalas e sua relação com o exame microbiológico. Ciência Animal. 14:39-45.

Pankaj A.S., Chhabra R. \& Sindhu N. 2013. Sub-clinical mastitis in Murrah buffaloes with special reference to prevalence, etiology and antibiogram. Buffalo Bull. 32:107-113.

Pizauro L.J.L., Silva D.G., Santana A.M., Clemente V., Lara G.H.B., Listoni F.J.P., Vaz A.C.N., Vidal-Martins A.M.C., Ribeiro M.G. \& Fagliari J.J. 2014. Prevalence and etiology of buffalo mastitis and milk somatic cell count in dry and rainy seasons in a buffalo herd from Analandia, São Paulo State, Brazil. Arq. Bras. Med. Vet. Zootec. 66:1703-1710.

Saini S.S., Sharma J.K. \& Kwatra M.S. 1994. Prevalence and etiology of subclinical mastitis among crossbreed cows and buffalos in Punjab. Indian J. Dairy Sci. 47:103-107.

Sampimon O., Barkema H.W., Berends I., Sol J. \& Lam T. 2009. Prevalence of intramammary infection in Dutch dairy herds. J. Dairy Res. 76:129-136.

Shahzad W., Altaf M., Ahmad M., Munir R., Amin M.T., Khan M.S., Sagar M.S., Khan M.A., Avais M., Akbar G. \& Mehmood F. 2013. Prevalence and molecular diagnosis of Staphylococcus aureus subclinical mastitis in lactating Nili-Ravi Buffaloes (Bubalus bubalis) at Livestock Experiment Station, Bahadurnagar, Okara, Pakistan. Buffalo Bull. 32:1041-1045.

Shome B.R., Das Mitra S., Bhuvana M., Krithiga N., Velu D., Shome R., Isloor S., Barbuddhe S.B. \& Rahman H. 2011. Multiplex PCR assay for species identification of bovine mastitis pathogens. J. Appl. Microbiol. 111: 1349-1356.

Tenhagen B.A., Hansen I., Reinecke A. \& Heuwieser W. 2009. Prevalence of pathogens in milk samples of dairy cows with clinical mastitis and in heifers at fi rst parturition. J. Dairy Res. 76:179-187.

Tiwari J.G., Chaudhary S.P., Tiwari H.K., Dutta T.K., Saikia P. \& Hazarika P. 2011. Microbial evaluation of market milk and milk-products of Mizoram, India with special reference to Staphylococcus aureus. Indian J. Dairy Sci. 81:429-431.

Viana R.B., Cardoso E.C., Gouveia I.M., Rezende M.L.G., Monteiro B.M. \& Araujo C.V. 2010. Avaliação da eficiência do Somaticell para o diagnóstico da contagem indireta de células somáticas no leite de búfalas. Revta Ciênc. Agrárias 1:24-30.

Vianni M.C.E. \& Lazaro N.S. 2003. Profile of antimicrobial susceptibility in strains of Gram positive cocci, negative catalase, isolated from buffalo subclinical mastitis. Pesq. Vet. Bras. 23:47-51.

Yesilmen S., Vural A., Erkan M.E. \& Yildirim I.H. 2014. Prevalence and antimicrobial susceptibility of Arcobacter species in cow milk, water buffalo milk and fresh village cheese. Int. J. Food Microbiol. 188:11-14. 